\title{
Effects of glycyrrhetic acid on human chronic myelogenous leukemia
}

\section{cells}

\section{Abstract}

Objectives: Chronic myelogenous leukemia (CML) is a type of blood cancer which is initially treated with imatinib (first Abl kinase inhibitor). However, some patients with $\mathrm{CML}$ are able to develop imatinib resistance. Several new generation drugs have been developed, but do not overcome this problem. Glycyrrhetic Acid (GA) is a plant-derived pentacyclic triterpenoid that exhibits multiple pharmacological properties for the treatment of cancers. The current study aims to investigate the effects of GA on K562 cell line (Bcr-Abl positive leukemia).

Materials and Methods: MTT cell proliferation assay was employed to evaluate the cytotoxic effect of GA compared with imatinib (positive control) against leukemia and normal blood cells. For detection of cell death, apoptotic/necrotic/healthy assay was performed against K562 cell line. To investigate kinase inhibitory activity of GA, the Abl1 kinase profiling assay and molecular docking study were performed.

Results: GA showed Abl kinase inhibitory activity with $\mathrm{IC}_{50}$ value of $29.2 \mu \mathrm{M}$ and induced apoptosis in K562 cell line after $6 \mathrm{~h}$ of treatment.

Conclusion: The current findings indicate that this class of plant extract could be a potential candidate for treatment of CML.

Key Words: Pentacyclic triterpenoid, Glycyrrhetic acid, Abl kinase, Apoptosis, K562 cells 


\section{Glisiretik Asit in insan kronik miyelojenöz lösemi hücreleri üzerindeki}

\section{etkileri}

\section{ÖZET}

Amaç: Kronik miyelojenöz lösemi (KML), başlangıçta imatinib (ilk Abl kinaz inhibitörü) ile tedavi edilen bir tür kan kanseridir. Fakat, KML`li bazı hastalar imatinib`e karşı direnç geliştirebilmektedir. Değişik yeni nesil ilaçlar geliştirilmiştir, ancak bu problemin üstesinden gelinememiştir. Glisiretik Asit (GA), kanser tedavisinde birçok farmakolojik özellik gösteren bitki kaynaklı bir pentasiklik triterpenoiddir. Bu çalışma, GA`nın K562 hücreleri (Bcr-Abl pozitif lösemi) üzerindeki etkilerini araştırmayı amaçlamaktadır.

Gereç ve Yöntemler: MTT hücre proliferasyon analizi, GA`nın imatinib`e (pozitif kontrol) kıyasla lösemi ve normal kan hücrelerine karşı sitotoksik etkisini değerlendirmek için kullanıldı. Hücre ölümünün tespiti için, apoptotik/nekrotik/sağlıklı hücre analizi K562 hücrelerine karşı yapıldı. GA'nın kinaz inhibe edici aktivitesini araştırmak için, Abl1 kinaz profil tahlili ve moleküler doking çalışmaları yapıldı.

Bulgular: GA, $29.2 \mu \mathrm{M}$ IC $_{50}$ değeri ile Abl kinaz inhibitör aktivitesi gösterdi ve 6 saatlik tedaviden sonra K562 hücre hattında apoptoz`a sebep oldu.

Sonuç: Mevcut bulgular, bu bitki özütü sınıfının KML tedavisi için potansiyel bir aday olabileceğini göstermektedir.

Anahtar kelimeler: Pentasiklik triterpenoid, Glisiretik asit, Abl kinaz, Apoptoz, K562 hücreleri 


\section{Introduction}

One of the major health problems all over the world is cancer. In 2015, over 8.7 million patients died from cancer globally, with approximately 17.5 million new cases $(1,2)$. Despite extensive efforts over the last several decades, cancer is still one of the most common cause of death in many developing nations. The death rate from cancer is predicted to be 17 million, with 26 million new cases each year by $2030(3,4)$. Due to this global increase in the cancer burden, a massive research effort has been made for discovery of effective and less toxic chemotherapeutic agents (5-8).

Over the past few years tyrosine kinases have raised a growing interest as drug target in anticancer drug discovery that play an important role in signal transduction, mitogenesis and other cellular activation processes (9-11). More than 25 kinase inhibitors are available for cancer therapy and there are currently many more promising candidates in clinical development $(12,13)$ after the approval of imatinib as the first Bcr-Abl tyrosine kinase inhibitor in 2002 (14). Although imatinib still continues to be initial choice in CML treatment, some patients with CML are able to develop drug resistance to imatinib $(14,15)$. This major limitation is becoming a significant concern for patients with the imatinibresistant chronic-phase CML (16). Several new generation drugs have been developed, but there are still no alternative drugs available to overcome this problem $(17,18)$.

Pentacyclic triterpenoids have emerged as a unique class of natural compounds and have been studied extensively for more than a century due to their effective therapeutic applications for the treatment of a wide spectrum of diseases and their high safety profile $(19,20)$. Recent studies have indicated that two different types of pentacyclic triterpenoids Celastrol and Gypsogenin exert anti-Abelson kinase 1 (Abl1) and anti-CML leukemia effects $(21,22)$.

GA is an olenane-type natural pentacyclic triterpenoid extracted from liquorice, which exhibits a promising anticancer activity on many cancer cells including human ovarian cancer, breast cancer, hepatocellular carcinoma, pituitary adenoma, human bladder cancer, lung cancer and leukemia (19,23-27). However, there is no reported research yet in the literature that displays Bcr-Abl 
inhibitory activity of GA. In the present study, we explored biological activities of GA against leukemia cell lines (Jurkat, MT-2 and K562) and normal cells of human blood (PBMC) and then evaluated its anti-tyrosine kinase activity. Furthermore, the apoptotic/necrotic analysis against K562 cell line and molecular docking with the Abl kinase domain were carried out using GA.

\section{Materials and Methods}

\subsection{Cell culture conditions and drug treatment}

The K562, Jurkat and MT-2 cell lines were cultured in RPMI 1640 (Wako Pure Chemical Industries, Osaka, Japan) medium with $10 \%$ fetal bovine serum (FBS) (Equitech-Bio, Texas, U.S.) and $89 \mu \mathrm{M} / \mathrm{mL}$ streptomycin (Meiji Seika Pharma, Tokyo, Japan) in a humid atmosphere at $37^{\circ} \mathrm{C}$ and $5 \% \mathrm{CO}_{2}$. Peripheral blood mononuclear cells (PBMC) (Precision Bioservices, Frederic, MD) were incubated in RPMI 1640 medium with 10\% human serum AB (HS) (Gemini, Woodland, CA) and $89 \mu \mathrm{M} / \mathrm{mL}$ streptomycin at $37^{\circ} \mathrm{C}$ (humid atmosphere, $5 \% \mathrm{CO}_{2}$ ). In experiments, the leukemia and PBMC cells were incubated in 24-well culture plates at $10^{5}$ and $10^{6} \mathrm{cells} / \mathrm{ml}$ concentration respectively for $48 \mathrm{~h}$. The stock solution of GA (Tokyo Chemical Industry Co. Ltd., Tokyo, Japan) and imatinib (Wako Pure Chemical Industries, Osaka, Japan) in concentrations of $2.5 \mathrm{mM}, 5$ $\mathrm{mM}, 10 \mathrm{mM}, 20 \mathrm{mM}$ and $30 \mathrm{mM}$ were prepared in DMSO (Wako Pure Chemical Industries, Osaka, Japan). The concentration of DMSO in the final culture medium was $1 \%$.

\subsection{MTT assay for cytotoxicity}

The MTT test was performed routinely as described in the literature $(28,29)$. GA and imatinib were cultured with cells in different concentrations (3-300 $\mu \mathrm{M})$. After $48 \mathrm{~h}$ of treatment, cells were incubated with MTT (Dojindo Molecular Technologies, Kumamoto, Japan) solution in medium for $4 \mathrm{~h}$. At the end of incubation, the solution was taken out and $100 \mu \mathrm{L}$ DMSO was added to each well. The absorbance of the solution was measured in a microplate reader Infinitive M1000 (Tecan, Groding, Austria) at a wavelength of $550 \mathrm{~nm}$ with background subtraction at $630 \mathrm{~nm}$. All experiments were run in triplicate and cell viability was calculated as the percentage of the viable control cells. $\mathrm{IC}_{50}$ values were 
estimated from the results of the MTT test described as the drug concentrations that reduced absorbance to $50 \%$ of control values.

\subsection{Detection of cell death}

After treatment of K562 cells with GA or imatinib at IC 50 concentrations for $6 \mathrm{~h}$, apoptotic/necrotic/healthy detection kit (PromoKine, Heidelberg, Germany) was performed according to PromoKine's instructions with the modifications (30). After the cells were harvested and washed with PBS, the cells were suspended with binding buffer (1x). After that, $50 \mu \mathrm{L}$ of binding buffer, $4 \mu \mathrm{L}$ of FITC-Annexin $V$ solution, $4 \mu \mathrm{L}$ of ethidium homodimer III solution and $4 \mu \mathrm{L}$ of Hoechst 33342 solution were added into the cells for $30 \mathrm{~min}$ at room temperature in the dark. Then, the cells were analyzed by a fluorescence microscope Biorevo Fluorescence BZ-9000 (Keyence, Osaka, Japan). The number of apoptotic cells (Annexin V), late apoptotic or necrotic cells (Annexin V and Ethidium homodimer III) and necrotic cells (Ethidium homodimer III) were counted as previously described (31).

\subsection{Abl1 tyrosine kinase profiling system}

The Abl1 kinase profiling assay (Promega Corporation, Madison, WI, USA) was performed as previously described with modifications (21). In this system, Abl1 kinase strip and its substrate were diluted with $95 \mu \mathrm{L}$ of $2.5 \mathrm{x}$ kinase reaction buffer and $15 \mu \mathrm{L}$ of $100 \mu \mathrm{M}$ ATP. Then, $2 \mu \mathrm{L}$ of kinase working stock and $2 \mu \mathrm{L}$ of ATP/substrate working stock were dispensed in the 384-well plate wells along with $1 \mu \mathrm{L}$ of compound solution at varying concentrations $(10-300 \mu \mathrm{M})$ in a buffer. Kinase reaction was incubated for $1 \mathrm{~h}$ at room temperature and then the activity of Abl1 kinase was detected using the ADP-Glo kinase assay (Promega Corporation). Abl1 inhibition profiling of $\mathrm{GA}$ in dose-response mode was measured by a luminescence microplate reader Infinitive M1000 (Tecan). IC 50 values of $\mathrm{GA}$ and imatinib required to reduce kinase activity by $50 \%$ was calculated using ImageJ software.

\subsection{Molecular modeling}

To investigate the binding modes of GA with Abl1 kinase, molecular docking study was performed using Molecular Operating Environment MOE 2015.10 (Chemical Computing Group, Montreal, Canada). The co-crystal structure of Abl 
tyrosine kinase with imatinib was obtained as the docking template from PDB data bank (PDB code: 1IEP) (32). Then, the Abl kinase and GA were prepared for molecular docking analysis including the addition of hydrogen atoms, the assignment of bond order, assessment of the correct protonation state and other default parameters. All molecular docking calculations were performed as previously described $(33,34)$.

\section{Results}

In the present study, we first performed MTT assay to investigate the antiproliferative effects of GA and imatinib against multiple human leukemia cells (K562 CML, Jurkat and MT-2) at various concentrations (10-300 $\mu \mathrm{M}$ ). Imatinib was selected as a model drug, considering its wide use in the treatment of CML. GA (Figure 1) and imatinib were dissolved in DMSO, diluted by culture medium and then treated with cultured cells for $48 \mathrm{~h}$. The $\mathrm{IC}_{50}$ values of these compounds on three cancer cell lines were shown in Table 1. GA exhibited concentration dependent inhibitory effect with $\mathrm{IC}_{50}$ values that were less than $75 \mu \mathrm{M}$ against all three cancer cell lines. It possessed most potent cytotoxic activity against imatinib-sensitive K562 cells with IC50 value of $51.6 \mu \mathrm{M}$ (Figure 2A), and IC $\mathrm{C}_{50}$ values of GA on Jurkat and MT-2 cells were $55.1 \mu \mathrm{M}$ and $70.2 \mu \mathrm{M}$, respectively, weaker than those of positive control. Next, the activity of target compound was examined on normal peripheral blood mononuclear cells (PBMCs) and compared with imatinib (Figure 2B). GA did not show considerable cytotoxicity against PBMCs with IC 50 value of $117.5 \mu \mathrm{M}$ and exhibited $~ 3.5$ times lower cytotoxicity than imatinib (Figure 2B). These results indicate that GA can act as an anti-CML agent and exhibits good selectivity for K562 cell lines over normal cells.

In order to investigate the process of apoptosis and necrosis, K562 cell line treated with $\mathrm{GA}$ or imatinib at $\mathrm{IC}_{50}$ concentrations were subjected to the annexin V/ ethidium homodimer III and Hoechst 33342 staining method and then observed by a fluorescence microscope (Figure 3 ). In the control experiment (1\% DMSO), all cells were healthy (blue staining) at $6 \mathrm{~h}$ (Figure $3 \mathrm{~A}$ ). On the other hand, the cells treated with GA and imatinib were stained mostly with healthy cells (blue), then apoptotic cells (green) and only a few necrotic cells (red) and late apoptotic or necrotic cells (both green and red) were detected at $6 \mathrm{~h}$ (Figure 
$3 A$ ), suggesting that the main cell death pathway of GA and imatinib was apoptosis in earlier time. The results showed that GA has 71\% apoptotic, $9 \%$ necrotic and 20\% late apoptotic/necrotic activities (Figure 3B). In contrast, the response of $\mathrm{K} 562$ cells upon $6 \mathrm{~h}$ imatinib treatment was $62 \%$ apoptosis, $11 \%$ necrosis and 27\% late apoptosis/necrosis (Figure 3B). Surprisingly, the results demonstrated that GA is able to induce more cell apoptosis than imatinib in $\mathrm{Bcr}$ Abl positive cells.

To explore the inhibition profile of GA on Bcr-Abl, we used Abl1 tyrosine activity based kinase assay. In this system, GA was screened at multiple concentrations (10-300 $\mu \mathrm{M})$ to determine its inhibitory profile on target kinasê (Abl1 tyrosine kinase). GA displayed a potential Bcr-Abl inhibitory activity with an $\mathrm{IC}_{50}$ value of $29.2 \mu \mathrm{M}$ as shown in Figure 4. Imatinib was included for comparison and showed stronger inhibitory effect than GA on Abl1. In order to understand the Bcr-Abl kinase inhibitory activity of GA, we next examined molecular modelling based on the co-crystal structure of Abl with imatinib as the docking model (PDB ID code: 1IEP). GA has fitted into the pocket forming five non-covalent interactions with four amino acid residues namely His361, Arg362, Asp381 and Ala380 (Figure 5). It is clear that GA carboxylate plays a pivotal role in activity by forming two $\mathrm{H}$ bonds with the basic amino acid Arg362. Binding energy values of GA and imatinib into the pocket are -7.2 and $-11.1 \mathrm{kcal} / \mathrm{mol}$, respectively which is in agreement with the experimental results.

\section{Discussion}

CML is a cancer of white blood cells mainly caused by the Bcr-Abl. Bcr-Abl tyrosine kinase inhibitors including imatinib have demonstrated significant therapeutic effects on many CML patients. However, resistance and toxicity of these inhibitors have been frequently reported in recent years. Therefore, novel $B c r-A b l$ inhibitors with high efficacy and low toxicity for treatment of $C M L$ are still searched. The accumulated evidence shows that GA has antitumor activities in breast cancer, ovarian cancer and acute promyelocytic leukemia, but its activity against $C M L$ is yet to be investigated.

In the present study, we explored cytotoxic activity of GA against different leukemic cell lines (K562, Jurkat and MT-2) and found that GA possesses a 
remarkable antiproliferative effect on K562 Bcr-Abl positive cell line. Moreover, GA induced programmed cell death in CML cells more efficiently than imatinib at $6 \mathrm{~h}$ of treatment and showed significant tumor selectivity on blood cells (PBMC and K562). To get more insights into GA molecular mechanism, we assessed its effect on Abl1 kinase which is amplified in K562 cells. As anticipated, GA inhibited Abl1 kinase with an $\mathrm{IC}_{50}$ of $29.2 \mu \mathrm{M}$. Molecular modeling simulation provided mechanistic information on the possible binding mode of GA into the ATP binding site of Abl1 kinase.

Recently, we have also revealed the activity of Gypsogenin, which is another pentacyclic triterpenoid, and its derivatives against K562 cell line (21). Considering previous and current data together, our findings suggest that PTs have promising anti-cancer roles and deserve particular attention in the treatment of CML. We believe that derivatization of GA will enhance its binding affinity into Bcr-Abl kinase, which in turn will enhance its anti-cancer activity. Further derivatizations and biological investigations for improvement of GA activity are ongoing.

Acknowledgements: The author thanks Prof. Masami Otsuka, Dr. Mikako Fujita, Dr. Mohamad O. Radwan and Dr. Nizar Turker for their helpful discussions on molecular modeling and English editing. The work was supported by Project P16111 from Japan Society for the Promotion of Science (JSPS).

Conflict of Interest: There is no conflict to declare.

\section{References}

1. Fitzmaurice C, Allen C, Barber RM, Barregard L, Bhutta ZA, Brenner H, Dicker DJ, Chimed-Orchir O, Dandona R, Dandona L, et al. Global, Regional, and national cancer incidence, mortality, years of life lost, years lived with disability, and disability-adjusted life-years for 32 cancer groups, 1990 to 2015. JAMA Oncol 4, 524, 2017.

2. Ferlay J, Soerjomataram II, Dikshit R, Esre S, Mathers C, Rebelo M, Parkin D M, Forman DD and Bray F. Cancer incidence and mortality worldwide: sources, methods and major patterns in GLOBOCAN 2012. Int J Cancer 5, E359-86, 2014. 
3. Thun MJ, DeLancey JO, Center MM, Jemal A, Ward EM. The global burden of cancer: Priorities for prevention. Carcinogenesis 1, 100-110, 2009.

4. Torre LA, Bray F, Siegel RL, Ferlay J, Lortet-tieulent J, Jemal A. Global cancer statistics, 2012. CA-Cancer J of Clin 2, 87-108, 2015.

5. Hoelder S, Clarke PA, Workman P. Discovery of small molecule cancer drugs: Successes, challenges and opportunities. Mol Oncol 2, 155-176, 2012.

6. Cragg GM, Pezzuto JM. Natural products as a vital source for the discovery of cancer chemotherapeutic and chemopreventive agents. Medicinal Principles and Practice 25, 41-59, 2016.

7. Ma X, Yu H. Global burden of cancer. Yale J Biol Med 3-4, 85-94, 2006.

8. Altıntop MD, Ciftci HI, Radwan MO, Sever B, Kaplancikli ZA, Ali TFS, Koga R, Fujita M, Otsuka M and Ozdemir A. Design, synthesis, and biological evaluation of novel 1,3,4-thiadiazole derivatives as potential antitumor agents against chronic myelogenous leukemia: Striking effect of nitrothiazole moiety. Molecules 23 (1), 59, 2018.

9. Schenk PW, Snaar-Jagalska BE. Signal perception and transduction: The role of protein kinases. BBA-Mol Cell Res 1, 1-24, 1999.

10. Fabbro D, Fendrich G, Guez V, Meyer T, Furet P, Mestan J, Griffin J D, Manley P W and Cowan-Jacob S W. Targeted therapy with imatinib: An exception or a rule? Handbook of Experimental Pharmacology 167, 361$389,2005$.

11. Wang Z, Cole PA. Catalytic mechanisms and regulation of protein kinases. Method Enzymol C, 1-21, 2014.

12. Borriello A, Caldarelli I, Bencivenga D, Stampone E, Perrotta S, Oliva A and Della Ragione F. Tyrosine kinase inhibitors and mesenchymal stromal cells: Effects on self-renewal, commitment and functions. Oncotarget 3, 5540-5565, 2017.

13. Gross S, Rahal R, Stransky N, Lengauer C, Hoeflich KP. Targeting cancer with kinase inhibitors. J Clin Invest 5, 1780-1789, 2015. 
14. Mughal A, Aslam HM, Khan AMH, Saleem S, Umah R, Saleem M. Bcr-Abl tyrosine kinase inhibitors- current status. Infec Agents Cancer 1, 23, 2013.

15. Soverini S, Hochhaus A, Nicolini FE, Gruber F, Lange T, Saglio G, Pane $F$, Muller MC, Ernst $T$, Rosti $G$, et al. BCR-ABL kinase domain mutation analysis in chronic myeloid leukemia patients treated with tyrosine kinase inhibitors: Recommendations from an expert panel on behalf of European LeukemiaNet. Blood 5, 1208-1215, 2011.

16. Barouch-bentov R. Mechanisms of drug-resistance in kinases. Expert Opin Inv Drug 2, 153-208, 2012.

17. Weisberg E, Manley PW, Cowan-Jacob SW, Hochhaus A, Griffin JD. Second generation inhibitors of BCR-ABL for the treatment of imatinibresistant chronic myeloid leukaemia. Nat Rev Cancer 5, 345-356, 2007.

18. Giles FJ, O'Dwyer M, Swords R. Class effects of tyrosine kinase inhibitors in the treatment of chronic myeloid leukemia. Leukemia 10, 1698-1707, 2009.

19. Salvador JAR, Leal AS, Valdeira AS, Gonçalves BMF, Alho DPS, Figueiredo SAC, Silvestre SM and Mendes VIS. Oleanane-, ursane-, and quinone methide friedelane-type triterpenoid derivatives: Recent advances in cancer treatment. Eur J Med Chem 142, 95-130, 2017.

20. Radwan MO, Ismail MAH, El-Mekkawy S, Ismail NSM, Hanna AG. Synthesis and biological activity of new $18 \beta$-glycyrrhetinic acid derivatives. Arab J Chem 3, 2016.

21. Ciftci HI, Ozturk SE, Ali TFS, Radwan M O, Tateishi Hiroshi, Koga Ryoko, Ocak Zeynep, Can Mustafa, Otsuka Masami and Fujita Mikako. The first pentacyclic triterpenoid gypsogenin derivative exhibiting anti-Abl1 kinase and anti-chronic myelogenous leukemia activities. Biol Pharm Bull 41, 570$574,2018$.

22. Lu Z, Jin Y, Qiu L, Lai Y, Pan J. Celastrol, a novel HSP90 inhibitor, depletes $\mathrm{Bcr-Abl}$ and induces apoptosis in imatinib-resistant chronic myelogenous leukemia cells harboring T315I mutation. Cancer Lett 2, 182-191, 2010. 
23. Sharma G, Kar S, Palit S, Das PK. 18ß-glycyrrhetinic acid induces apoptosis through modulation of $\mathrm{Akt} / \mathrm{FOXO} 3 \mathrm{a} / \mathrm{Bim}$ pathway in human breast cancer MCF-7 cells. J Cell Physiol 5, 1923-1931, 2012.

24. Zhu J, Chen M, Chen N, Ma A, Zhu C, Zhao R, Jiang M, Zhou J, Ye L, Fu $\mathrm{H}$, et al. Glycyrrhetinic acid induces $\mathrm{G} 1$-phase cell cycle arrest in human non-small cell lung cancer cells through endoplasmic reticulum stress pathway. Int J Oncol 3, 981-988, 2015.

25. Liu D, Song D, Guo G, Wang R, Lv J, Jing Y and Zhao L. The synthesis of $18 \beta$-glycyrrhetinic acid derivatives which have increased antiproliferative and apoptotic effects in leukemia cells. Bioorgan Med Chem 16, 54325439, 2007.

26. Pirzadeh S, Fakhari S, Jalili A, Mirzai S, Ghaderi B and Haghshenas V. Glycyrrhetinic Acid induces apoptosis in leukemic HL60 cells through upregulating of CD95 / CD178. Int J Mol Cell Med 4, 272-8, 2014.

27. Gao Z, Kang $X, \mathrm{Hu} J$, Ju $Y$ and $X u C$. Induction of apoptosis with mitochondrial membrane depolarization by a glycyrrhetinic acid derivative in human leukemia K562 cells. Cytotechnology 4, 421-428, 2012.

28. Ali TFS, Iwamaru K, Ciftci HI, Koga R, Matsumoto M, Oba Y, Kurosaki H, Fujita M, Okamoto Y, Umezawa K, et al. Novel metal chelating molecules with anticancer activity. Striking effect of the imidazole substitution of the histidine-pyridine-histidine system. Bioorgan Med Chem 17, 5476-5482, 2015.

29. Bayrak N, Yildirim H, Tuyun AF, Kara EM, Celik BO, Gupta GK, Ciftci HI, Fujita M, Otsuka M and Nasiri HR. Synthesis, computational study, and evaluation of in vitro antimicrobial, antibiofilm, and anticancer activities of new sulfanyl aminonaphthoquinone derivatives. Lett Drug Des Discov 6, 647-661, 2017.

30. Karabacak M, Altıntop M, Çiftçi Hi, Koga R, Otsuka M, Fujita M and Özdemir A. Synthesis and evaluation of new pyrazoline derivatives as potential anticancer agents. Molecules 10, 19066-19084, 2015. 
31. Tateishi H, Monde K, Anraku K, Koga R, Hayashi Y, Ciftci HI, Demirci H, Higashi T, Motoyama $\mathrm{K}$, Arima $\mathrm{H}$, et al. A clue to unprecedented strategy to HIV eradication: "Lock-in and apoptosis." Sci Rep 1, 2017.

32. Nagar B, Bornmann W, Pellicena P, Schindler T, Veach DR, Miller WT and Clarkson B. Crystal structures of the kinase domain of C-Abl in complex with the small molecule inhibitors PD173955 and imatinib (STI-571). Cancer Res 15, 4236-4243, 2002.

33. Radwan MO, Sonoda S, Ejima T, Tanaka A, Koga R, Okamoto Y, Fujita M and Otsuka M. Zinc-mediated binding of a low-molecular-weight stabilizer of the host anti-viral factor apolipoprotein B mRNA-editing enzyme, catalytic polypeptide-like 3G. Bioorgan Med Chem 18, 4398-4405, 2016.

34. Koga R, Radwan MO, Ejima T, Kanemaru Y, Tateishi H, Ali TFS, Ciftci HI, Shibata Y, Taguchi Y, Inoue J, Otsuka M, et al. A Dithiol Compound Binds to the Zinc finger protein TRAF6 and suppresses its ubiquitination. ChemMedChem 23 1935-1941, 2017. 